\title{
Hubungan Mekanisme Koping dengan Kualitas Hidup pada Klien Diabetes Melitus Tipe 2 di Wilayah Kerja Puskesmas Kaliwates-Jember
}

\section{(Correlation between Coping Mechanism and the Quality of Life in Client of Type 2 Diabetes Melitus at the Kaliwates Primary Health Care-Jember)}

\author{
Putri Hidayatur Rochmah, Hanny Rasni, Kholid Rosyidi Muhammad Nur \\ Fakultas Keperawatan Universitas Jember \\ JI. Kalimantan No. 37 Kampus Tegal Boto Jember Telp./Fax. (0331) 323450 \\ e-mail: hannyrasni@yahoo.co.id
}

\begin{abstract}
Type 2 Diabetes Mellitus (T2DM) is one of the progressive chronic diseases that cause various complications. Complications that are often experienced by T2DM clients such as foot injuries can affect the quality of life. One of the factors influencing the quality of life is a coping mechanism. This study aimed to analyze the relationship between coping mechanisms and the quality of life of clients of T2DM in the working area of Kaliwates Primary Health Center, Jember. The design of this research was analytical with a cross-sectional approach. Respondents in this study were 84 and obtained by a purposive sampling technique. The data collection method used the Cope Inventory and DQOL (Diabetes Quality of Life) questionnaire. The data analysis used Spearman correlation test with a significance level of 0.05 . The results of the study showed that the most used coping was emotionalfocused coping with an average value was 3.02 and the majority of respondents had a high quality of life of 67 respondents (79.8\%). There is no correlation between coping mechanisms and the quality of life of clients of T2DM in the work area of Kaliwates Primary Health Center, Jember ( $p$-value $=0.273$ ). Other factors such as anxiety, depression, physical activity, control of blood sugar, fatigue, and stress need to be assessed to improve the quality of life for clients of T2DM.
\end{abstract}

Keywords: type 2 diabetes melitus, coping mechanism, the quality of life

\begin{abstract}
Abstrak
Diabetes Melitus Tipe 2 (DMT2) merupakan salah satu penyakit kronis progresif yang menimbulkan berbagai komplikasi. Komplikasi yang sering dialami klien DM tipe 2 seperti luka pada kaki dapat mempengaruhi kualitas hidup. Salah satu faktor yang mempengaruhi kualitas hidup adalah mekanisme koping. Penelitian ini bertujuan menganalisis hubungan antara mekanisme koping dengan kualitas hidup klien DM tipe 2 di wilayah kerja Puskesmas Kaliwates Kabupaten Jember. Desain penelitian korelasional analitik dengan pendekatan cross-sectional. Sebanyak 84 responden diperoleh dengan purposive sampling. Pengumpulan data menggunakan kuesioner Cope Inventory dan Diabetes Quality of Life (DQOL). Analisis data penelitian menggunakan Spearman dengan tingkat signifikansi 0,05. Hasil penelitian menunjukkan koping yang paling banyak digunakan responden yaitu koping berfokus pada emosi dengan nilai rata-rata sebesar 3,02 dan mayoritas responden memiliki kualitas hidup tinggi sebesar 67 responden $(79,8 \%)$. Tidak ada hubungan antara mekanisme koping dengan kualitas hidup klien DM tipe 2 di wilayah kerja Puskesmas Kaliwates Kabupaten Jember ( $p$-value $=0,273$ ). Faktorfaktor lain seperti kecemasan, depresi, aktivitas fisik, kontrol gula darah, kelelahan, dan stres perlu dikaji untuk meningkatkan kualitas hidup klien DM tipe 2
\end{abstract}

Kata kunci: diabetes melitus tipe 2, mekanisme koping, kualitas hidup 


\section{Pendahuluan}

Diabetes Melitus (DM) merupakan suatu penyakit kronis progresif yang menimbulkan berbagai komplikasi terutama pada mata, saraf, pembuluh darah, ginjal, dan jantung yang banyak terjadi pada masyarakat [1]. Data menunjukkan sekitar 425 juta orang diseluruh dunia mengalami DM [2]. Indonesia menjadi salah satu dari sepuluh besar negara dengan jumlah klien DM tertinggi di dunia yaitu 10,3 juta [2]. Berdasarkan data yang diperoleh dari Puskesmas Kaliwates tahun 2018 dari bulan Januari sampai dengan bulan Juli jumlah kunjungan klien DM tipe 2 sebanyak 159 orang. Jumlah kunjungan klien DM tipe 2 yang tinggi menjadi gambaran bahwa di Kabupaten Jember jumlah klien DM tipe 2 masih tinggi. Meningkatnya prevalensi DM menjadi faktor perlunya pengukuran kualitas hidup pada klien DM tipe 2 [3].

Hasil penelitian Siwiutami di Puskesmas Purwosari Semarang, gambaran kualitas hidup dari pasien DM hasilnya yaitu dari 91 responden sebagian besar memiliki kualitas hidup rendah yaitu 53 orang $(58,92 \%)$, dan sisanya yaitu 38 orang $(41,8 \%)$ memiliki kualitas hidup baik [4]. Kualitas hidup menjadi salah satu faktor yang dapat mempengaruhi kondisi kesehatan seseorang [5]. Kualitas hidup merupakan tujuan utama dari perawatan pada klien DM, sehingga sangat dibutuhkan kualitas hidup yang baik untuk tercapainya perawatan yang baik [6].

Sumber stres yang dialami oleh klien DM terjadi akibat berbagai perubahan fisik yang mengharuskan kepatuhan klien untuk selalu melakukan pengontrolan penyakit [7] Selain itu treatment seperti diet atau pengontrolan makan, konsumsi obat, olahraga, kontrol gula darah yang harus dijalani klien DM sepanjang hidupnya juga berkaitan dengan terjadinya stres [8]. Strategi koping, respon koping, atau mekanisme koping merupakan suatu respon ketika seseorang mendapatkan stressor [9]. Koping yang sehat sangat diperlukan klien DM untuk menjaga status kesehatan dan kualitas hidup bagi klien DM [10]. Faktor yang mempengaruhi kualitas hidup klien DM salah satunya yaitu faktor psikologis seperti strategi koping, tingkat depresi, tingkat kecemasan, keyakinan kesehatan, dukungan sosial, dan kepribadian [11]. Stres yang berkepanjangan akan mempengaruhi kualitas hidup pasien, untuk mengurangi atau mengatasi stres memerlukan suatu mekanisme penyelesaian masalah atau koping yang efektif [9].

e-Journal Pustaka Kesehatan, vol.7 (no. 2), Mei 2019
Klien yang mengalami penyakit kronis akan mengalami mekanisme koping yang berbeda-beda setiap individunya [12]. Agar bisa menerima dan berdamai dengan stressor yang muncul, seseorang harus mampu menggunakan mekanisme koping yang ada [13]. Hasil penelitian pada klien DM dari 40 klien sebanyak 12 orang $(40 \%)$ memiliki mekanisme koping yang adaptif dan 18 orang (60\%) memiliki mekanisme koping maladaptif [14].

Pelaksanaan mekanisme koping adaptif yang dapat dilakukan melalui intervensi keperawatan peningkatan koping sangat diperlukan untuk meningkatkan kualitas hidup klien DM tipe 2 menjadi lebih baik. Penelitian ini bertujuan untuk menganalisa hubungan mekanisme koping dengan kualitas hidup klien diabetes melitus tipe 2 di Wilayah Kerja Puskesmas Kaliwates Kabupaten Jember.

\section{Metode Penelitian}

Penelitian ini merupakan penelitian korelasional analitk dengan pendekatan cross sectional. Populasi penelitian adalah semua klien DM tipe 2 yang masuk dalam data Puskesmas Kaliwates dari bulan Januari 2018 sampai bulan Juli 2018 sebanyak 159 orang. Sampel yang digunakan sebanyak 84 responden dengan teknik purposive sampling. Penelitian ini dilakukan secara door to door di Wilayah Kerja Puskesmas Kaliwates, Kecamatan Kaliwates, Kabupaten Jember. Kuesioner yang digunakan pada penelitian ini Cope Inventory dan Diabetes Quality of Life (DQOL).

Analisis data yang digunakan yaitu analisis univariat dan bivariat. Analisis univariat untuk menggambarkan karakteristik dari masing-masing variabel yang diteliti. Analisis bivariat menggunakan uji Spearman dengan tingkat signifikansi 0,05.

\section{Hasil}

\section{Karakteristik Responden}

Tabel 1. Distribusi Berdasarkan Usia pada Klien DM Tipe 2 di Wilayah Kerja Puskesmas Kaliwates Kabupaten Jember (Januari, 2019; n: 84)

\begin{tabular}{llc}
\hline Variabel & Mean & SD \\
\hline Usia (Tahun) & 57,64 & 8,84 \\
\hline
\end{tabular}

Tabel 1 menunjukkan nilai rata-rata usia 
dari klien DM tipe 2 di Wilayah Kerja Puskesmas Kaliwates sebesar 57,64 tahun dengan nilai standar deviasi berdasarkan usia yaitu 8,84.

Tabel 2. Distribusi Berdasarkan Lama Mengalami DM pada Klien DM Tipe 2 di Wilayah Kerja Puskesmas Kaliwates Kabupaten Jember (Januari, 2019; n: 84)

\begin{tabular}{lccc}
\hline Variabel & Mean & Median & $\begin{array}{c}\text { Min- } \\
\text { Maks }\end{array}$ \\
\hline Lama Mengalami & 6,17 & 5,00 & $0,25-$ \\
DM (Tahun) & & & 15,00 \\
\hline
\end{tabular}

Tabel 2 hasil distribusi dari lama mengalami DM pada klien DM tipe 2 didapatkan hasil nilai tengahnya yaitu 5 tahun dengan lama mengalami DM minimal pada klien 0,25 tahun dan lama mengalami DM maksimal pada klien 15 tahun. Sedangkan rata-rata lama mengalami DM pada klien yaitu 6,17 tahun.

Tabel 3. Distribusi Responden Berdasarkan Jenis Kelamin, Pendidikan, dan Pekerjaan pada Klien DM Tipe 2 di Wilayah Kerja Puskesmas Kaliwates Kabupaten Jember (Januari, 2018; n: 84)

\begin{tabular}{lcc}
\hline \multicolumn{1}{c}{ Variabel } & Jumlah & $\begin{array}{c}\text { Presentase } \\
\text { (\%) }\end{array}$ \\
\hline $\begin{array}{l}\text { 1. Jenis Kelamin } \\
\text { a. Laki-laki }\end{array}$ & 34 & 40,5 \\
b. Perempuan & 50 & 59,5 \\
\hline Total & 84 & 100 \\
\hline 2. Pendidikan & & \\
Terakhir & & \\
\hline$\quad$ a. Tidak Sekolah & 23 & 27,4 \\
b. SD & 13 & 15,5 \\
c. SMP & 15 & 17,9 \\
d. SMA & 29 & 34,5 \\
$\quad$ e. PT & 4 & 4,8 \\
\hline Total & 84 & 100 \\
\hline 3. Pekerjaan & & \\
$\quad$ a. Tidak Bekerja & 20 & 23,8 \\
$\quad$ b. Ibu Rumah & 26 & 31,0 \\
$\quad$ Tangga & & \\
$\quad$ c. Wiraswasta & 17 & 20,2 \\
$\quad$ d. PNS/ & 8 & 9,5 \\
$\quad$ Pensiunan & & \\
$\quad$ e. Pedagang & 6 & 7,1 \\
$\quad$ f. Karyawan & 6 & 7,1 \\
$\quad$ Swasta & & \\
g. Tukang Becak & 1 & 1,2 \\
\hline Total & 84 & 100 \\
\hline
\end{tabular}

e-Journal Pustaka Kesehatan, vol.7 (no. 2), Mei 2019
Hasil distribusi data pada tabel 3 jenis kelamin yang lebih banyak mengalami DM tipe 2 yaitu perempuan sebanyak 50 orang $(59,5 \%)$, sedangkan jenis kelamin laki-laki sebanyak 34 orang $(40,5 \%)$. Pendidikan responden terakhir paling banyak adalah SMA sebanyak 29 orang $(34,5 \%)$. Jenis pekerjaan dari responden yang paling banyak yaitu ibu rumah tangga sebanyak 26 orang $(31 \%)$.

\section{Mekanisme Koping}

Tabel 4. Nilai Rata-Rata Mekanisme Koping pada Klien DM Tipe 2 di Wilayah Kerja Puskesmas Kaliwates Kabupaten Jember (Januari, 2019; n: 84)

\begin{tabular}{lccc}
\hline Variabel & Mean & Median & Min-Maks \\
\hline $\begin{array}{l}\text { Mekanisme } \\
\text { Koping }\end{array}$ & 77,96 & 78,00 & $73-90$ \\
\hline
\end{tabular}

Hasil yang didapatkan dari tabel 4 menunjukkan bahwa nilai tengah dari variabel mekanisme koping yaitu 78 dengan nilai minimal variabel mekanisme koping dari responden yaitu 73 dan nilai maksimal 90 . Sedangkan untuk nilai rata-rata variabel mekanisme koping yaitu 77,96 .

Tabel 5. Nilai Rata-rata Koping Berfokus Masalah, Penghindaran, Dukungan Sosial, dan Koping Berfokus Emosi pada Klien DM Tipe 2 di Wilayah Kerja Puskesmas Kaliwates Kabupaten Jember (Januari, 2018; $\mathrm{N}=84$ )

\begin{tabular}{lccc}
\hline & Mean & Median & Min-Maks \\
\hline $\begin{array}{l}\text { Koping } \\
\begin{array}{l}\text { Berfokus } \\
\text { Masalah }\end{array}\end{array}$ & 2,62 & 2,67 & $2,33-3,17$ \\
\hline Penghindaran & 2,91 & 3,00 & $2,33-4,00$ \\
\hline $\begin{array}{l}\text { Dukungan } \\
\text { Sosial }\end{array}$ & 2,41 & 2,33 & $2,17-2,83$ \\
\hline $\begin{array}{l}\text { Koping } \\
\text { Berfokus }\end{array}$ & 3,02 & 3,00 & $2,70-3,80$ \\
Emosi & & & \\
\hline
\end{tabular}

Berdasarkan tabel 5 hasil nilai rata-rata tertinggi koping yang digunakan pada klien yaitu koping berfokus emosi sebesar 3,02, sedangkan yang nilai rata-rata terendah pada penggunaan koping dukungan sosial yaitu sebesar 2,41.

Tabel 6. Nilai Rata-rata Indikator Mekanisme Koping Klien pada DM Tipe 2 di Wilayah Kerja Puskesmas Kaliwates 
Rochmah, et al, Hubungan Mekanisme Koping dengan Kualitas Hidup pada Klien ...

Kabupaten Jember (Januari, 2018; $\mathrm{n}=84$ )

\begin{tabular}{|c|c|c|c|}
\hline Indikator & Mean & Median & Min-Maks \\
\hline Koping Aktif & 2,99 & 3,00 & $2,5-4,0$ \\
\hline Pengalihan Diri & 2,97 & 3,00 & $2,0-4,0$ \\
\hline Penerimaan & 3,03 & 3,00 & $2,5-4,0$ \\
\hline $\begin{array}{l}\text { Penggunaan } \\
\text { Pertolongan }\end{array}$ & 2,95 & 3,00 & $2,0-4,0$ \\
\hline Penyusunan Positif & 3,03 & 3,00 & $2,5-3,5$ \\
\hline Perencanaan & 2,76 & 3,00 & $2,0-3,5$ \\
\hline Koping Agama & 3,09 & 3,00 & $2,0-4,0$ \\
\hline Humor & 3,02 & 3,00 & $2,5-4,0$ \\
\hline Ketidakberdayaan & 2,91 & 3,00 & $2,0-4,0$ \\
\hline Penolakan & 2,85 & 3,00 & $1,0-4,0$ \\
\hline $\begin{array}{l}\text { Penggunaan } \\
\text { Dukungan } \\
\text { Emosional }\end{array}$ & 2,05 & 2,00 & $1,0-3,0$ \\
\hline Penggunaan Zat & 2,98 & 3,00 & $2,0-4,0$ \\
\hline $\begin{array}{l}\text { Menyalahkan Diri } \\
\text { Sendiri }\end{array}$ & 2,11 & 2,00 & $1,0-3,0$ \\
\hline Pelepasan & 2,21 & 2,00 & $2,5-3,5$ \\
\hline
\end{tabular}

Hasil nilai rata-rata tertinggi dari indikator mekanisme koping pada tabel 6 yaitu pada indikator koping agama sebesar 3,09, sedangkan untuk nilai rata-rata terendah terdapat pada indikator penggunaan dukungan emosional sebesar 2,05. Nilai tengah dari masing-masing indikator yang paling banyak yaitu nilai 3 , sedangkan indikator penggunaan dukungan emosional, menyalahkan diri sendiri, dan pelepasan memiliki nilai tengah 2 .

\section{Kualitas Hidup}

Tabel 7. Nilai Rata-Rata Kualitas Hidup pada Klien DM tipe 2 di Wiiayah Kerja Puskesmas Kaliwates Jember (Januari, 2019; n=84)

\begin{tabular}{lccc}
\hline Variabel & Mean & Median & Min-Maks \\
\hline $\begin{array}{l}\text { Kualitas } \\
\text { Hidup }\end{array}$ & 88,74 & 91,00 & $60-104$ \\
\hline
\end{tabular}

Hasil yang didapatkan pada tabel 7 yaitu nilai tengahnya sebesar 91 dengan minimal variabel kualitas hidup yaitu 60 dan untuk nilai maksimalnya sebesar 104. Sedangkan untuk nilai rata-rata variabel kualitas hidup yaitu 88,74 .

Tabel 8. Distribusi Kualitas Hidup pada Klien DM Tipe 2 di Wilayah Kerja Puskesmas Kaliwates Kabupaten Jember (Januari, 2019; $\mathrm{n}=84$ )

e-Journal Pustaka Kesehatan, vol.7 (no. 2), Mei 2019

\begin{tabular}{ccc}
\hline Variabel & Jumlah & $\begin{array}{c}\text { Presentase } \\
(\mathbf{\%})\end{array}$ \\
\hline $\begin{array}{c}\text { Kualitas Hidup } \\
\text { a. Kualitas } \\
\text { hidup rendah }\end{array}$ & 0 & 0 \\
$\begin{array}{l}\text { b. Kualitas } \\
\text { hidup sedang }\end{array}$ & 17 & 20,2 \\
$\begin{array}{l}\text { c. Kualitas } \\
\text { hidup tinggi }\end{array}$ & 67 & 79,8 \\
\hline Total & 84 & 100 \\
\hline
\end{tabular}

Berdasarkan tabel 8 didapatkan hasil mayoritas kualitas hidup yang dimiliki klien DM tipe 2 di wilayah kerja Puskesmas Kaliwates Kabupaten Jember yaitu kualitas hidup tinggi sebanyak 67 orang $(79,8 \%)$, sedangkan kualitas hidup sedang sebanyak 17 orang $(20,2 \%)$.

Tabel 9. Nilai Rata-Rata Indikator Kualitas Hidup pada Klien DM Tipe 2 di Wilayah Kerja Puskesmas Kaliwates Kabupaten Jember (Januari, 2019; $n=84$ )

\begin{tabular}{lccc}
\hline \multicolumn{1}{c}{$\begin{array}{l}\text { Indikator } \\
\text { Variabel }\end{array}$} & Mean & Median & Min-Maks \\
\hline Kesehatan Fisik & 3,03 & 3,09 & $1,91-3,64$ \\
\hline Psikologis & 3,27 & 3,33 & $2,00-4,00$ \\
\hline $\begin{array}{l}\text { Hubungan } \\
\text { Sosial }\end{array}$ & 3,19 & 3,25 & $2,25-4,00$ \\
\hline Lingkungan & 3,31 & 3,50 & $2,25-3,50$ \\
\hline
\end{tabular}

Tabel 9 menunjukan bahwa indikator kualitas hidup dengan nilai rata-rata tertinggi yaitu lingkungan dengan nilai 3,31 dengan nilai tengah 3,50 dan nilai minimal 2,25 serta maksimal 3,50 . Sedangkan untuk nilai rata-rata terendah pada indikator kesehatan fisik dengan nilai 3,03 dengan nilai tengah 3,09 dan untuk nilai minimal 1,91 serta nilai maksimal 3,64.

Tabel 10. Analisa hubungan mekanisme koping dengan kualitas hidup pada klien DM Tipe 2 di Wilayah Kerja Puskesmas Kaliwates Kabupaten Jember (Januari, 2019; $\mathrm{n}=84$ )

\begin{tabular}{lll}
\hline Variabel & & Kualitas Hidup \\
\hline $\begin{array}{l}\text { Mekanisme } \\
\text { Koping }\end{array}$ & $p$-value & 0,273 \\
\cline { 2 - 3 } & $\mathrm{N}$ & 84 \\
\hline
\end{tabular}

Tabel 10 menunjukkan analisis hubungan mekanisme koping dan kualitas hidup klien DM tipe 2 di Wilayah Kerja Puskesmas Kaliwates 
Kabupaten Jember dengan menggunakan uji statistik Spearman hasilnya sebesar 0,273 sehingga $\mathrm{Ha}$ gagal diterima artinya tidak terdapat hubungan antara variabel mekanisme koping dengan kualitas hidup klien DM Tipe 2.

\section{Pembahasan}

\section{Karakteristik Responden}

Rata-rata usia dari klien yang DM tipe 2 pada penelitian ini yaitu 57,64 tahun. Penurunan dari semua sistem pada tubuh bisa terjadi karena faktor usia. Bertambahnya usia menyebabkan insulin berada pada kondisi resistensi yang mengakibatkan gula darah tidak stabil sehingga kejadian DM semakin banyak terjadi [15]. Rata-rata lama klien mengalami DM tipe 2 yaitu 6,17 tahun. Komplikasi akan menjadi semakin tinggi jika waktu seseorang mengalami DM semakin lama [16].

Hasil penelitian jenis kelamin paling banyak yang mengalami DM tipe 2 yaitu perempuan sebanyak 50 orang $(59,5 \%)$. Peluang meningkatnya IMT (Indeks Massa Tubuh) dari perempuan menyebabkan terjadinya DM tipe 2 lebih banyak terjadi pada perempuan [17]. Pendidikan seseorang yang tinggi akan mempengaruhi seseorang dalam mempunyai banyak pengetahuan terkait kesehatan. Seseseorang akan memiliki kesadaran untuk menjaga kesehatannya dengan pengetahuan yang dimiliki tersebut [18]. Hasil dari penelitian pada klien DM tipe 2 paling banyak pekerjaan dari 84 responden yaitu ibu rumah tangga sebanyak 26 orang (31\%). Aktivitas fisik yang dilakukan pada diabetes bermanfaat untuk menurunkan kadar gula darah, memperbaiki kontrol diabetes, meningkatkan fungsi jantung dan pernafasan, menurunkan berat badan dan meningkatkan kualitas hidup. Beberapa aktifitas yang dilakukan pada ibu rumah tangga tergolong dalam aktifitas yang ringan [15].

\section{Mekanisme Koping}

Berdasarkan hasil penelitian pada klien DM tipe 2 di wilayah kerja Puskesmas Kabupaten Jember rata-rata mekanisme koping sebesar 77,96 . Nilai rata-rata terendah indikator mekanisme koping yaitu indikator dukungan emosional dengan nilai 2,05 dan rata-rata indikator tertinggi pada koping agama 3,09.

Penelitian yang mendukung yaitu pada klien DM dewasa cenderung menggunakan koping berfokus emosi dalam menghadapi depresi akibat DM tipe 2 [19]. Penelitan pada klien DM tipe 2 di Puskesmas Patrang hasilnya yaitu nilai rata-rata mekanisme koping yang didapat sebesar 76,55 dengan indikator dengan rata-rata rendah pada penggunaan dukungan emosional sedangkan indikator dengan nilai rata-rata tertinggi pada penggunaan zat [20].

Hasil penggunaan koping yang memiliki rata-rata tertinggi yaitu koping berfokus pada emosi sebesar 3,02 yang artinya kebanyakan klien menggunakan koping berfokus pada emosi dalam menghadapi DM tipe 2 yang dialami. Penelitian yang mendukung yaitu pada penelitian dengan hasil koping yang digunakan oleh klien DM biasanya merupakan koping yang berfokus pada emosi [21]. Koping berfokus pada emosi ini dilakukan ketika klien mengetahui bahwa hanya sedikit tindakan yang bisa dilakukan untuk mengubah kondisi yang penuh dengan tekanan [22].

Hasil penggunaan koping dukungan sosial memiliki rata-rata terendah sebesar 2,41 artinya hanya sedikit klien yang menggunakan dukungan sosial dalam menghadapi DM tipe 2. Kebanyakan klien memberikan jawaban tidak setuju pada pernyataan dukungan emosional yang klien dapatkan. Penelitian ini didukung oleh penelitian yang dilakukan di Puskesmas Patrang indikator dengan rata-rata terendah pada penggunaan dukungan emosional [20]. Dukungan emosional digunakan apabila individu berusaha untuk memperoleh dukungan berupa moral, perhatian dari orang disekitarnya, serta simpati [23].

\section{Kualitas Hidup}

Distribusi kualitas hidup yang dimiliki responden dalam penelitian mayoritas pada kategori kualitas hidup tinggi yaitu 67 orang $(79,8 \%)$. Penelitian yang mendukung yaitu penelitian di Poli Endokrin di salah satu rumah sakit negeri di Jawa Barat dengan hasil kualitas hidup yang dimiliki klien DM Tipe 2 kebanyakan tinggi yaitu sebanyak 50 orang $(56,18 \%)$ dari 89 responden [24].

Indikator dengan nilai tertinggi yaitu lingkungan dengan nilai rata-rata 3,31 . Penelitian yang mendukung yaitu [enelitian pada klien DM tipe 2 di Poli Endokrin hasilnya domain lingkungan memiliki rata-rata paling tinggi yaitu 3,48 . Hasil penelitian yang didapatkan sebagian besar klien merasa puas dengan keadaan lingkungannya seperti lama berobat dan layanan kesehatan yang ada [24]. Penelitian yang mendukung yaitu penelitian yang mengatakan bahwa jika dilihat dari indikator lingkungan, responden merasa puas dengan informasi baru yang didapatkan dari pelayanan kesehatan di 
poli penyakit dalam RSUD Cianjur. Latar belakang dari kepribadian seseorang serta situasi lingkungan dapat mempengaruhi persepsi pengetahuan dari seseorang dalam memaknai kualitas hidupnya [5].

Indikator dengan nilai terendah yaitu kesehatan fisik dengan nilai rata-rata sebesar 3,03 . Berdasarkan hasil penelitian sebagian besar klien merasa puas dengan diet, tidur, kemampuan melakukan aktivitas, olahraga, dan waktu santai yang yang dirasakan. Penelitian yang mendukung dilakukan pada klien DM tipe 2 di RS PKU Muhammadiyah Bantul hasilnya pada domain fisik kedua kelompok yaitu monoterapi dan terapi kombinasi tidak merasa terbatas dalam melakukan pekerjaan serta aktivitas sehari-hari [25]. DM dapat memberikan dampak yang mempengaruhi kesehatan fisik secara langsung maupun tidak langsung, sehingga bisa menurukan kualitas hidup [5]. Hasil penelitian terkait dampak dari DM seperti rasa nyeri kesemutan pada tangan dan kaki, kesulitan tidur, sering buang air kecil sebagian besar klien menjawab sering, jarang hingga tidak pernah klien rasakan.

\section{Hubungan Mekanisme Koping dengan Kualitas Hidup pada Klien DM Tipe 2}

Berdasarkan penelitian yang telah dilakukan didapatkan hasil $p$-value 0,273 yang artinya tidak ada hubungan antara mekanisme koping dengan kualitas hidup klien DM tipe 2 di wilayah kerja Puskesmas Kaliwates. Penelitian yang mendukung yaitu dilakukan di Poli Penyakit Dalam RS Tingkat III Baladhika Husada Jember hasil yang didapatkan dari uji Spearman nilai $p$-value 0,44 menunjukan tidak ada hubungan antara pemberdayaan diri dengan kualitas hidup pada klien DM [26]

DM dapat berdampak negatif pada kualitas hidup terkait kesehatan klien [27]. Dampak negatif yang mempengaruhi kualitas hidup klien DM seperti dampak psikologis mengalami penyakit kronis, pembatasan diet, perubahan dalam kehidupan sosial, dan komplikasi kronis. Koping yang sehat seperti peningkatan koping, latihan kontrol impuls, dan dukungan pengambilan keputusan sangat diperlukan oleh klien DM agar status kesehatan dan kualitas hidup klien dalam kondisi yang baik $[10,28]$.

Hasil penelitian yaitu tidak ada hubungan antara mekanisme koping dengan kualitas hidup. Kemungkinan tidak hanya mekanisme koping saja yang menjadi faktor yang mempengaruhi kualitas hidup klien DM tipe 2 di wilayah kerja Puskesmas Kaliwates, namun masih banyak faktor lainnya yang dapat mempengaruhi kualitas hidup dari klien. Mayoritas kualitas hidup klien pada penelitian yaitu baik karena lingkungan disekitar klien juga mendukung, dibuktikan dengan hasil nilai ratarata tertinggi variabel kualitas hidup penelitian ini yaitu domain lingkungan. Sebagian besar klien juga merasakan kepuasan pada kesehatan fisik, psikologis, serta hubungan sosial yang ada. Selain itu faktor lain yang bisa mempengaruhi kualitas hidup klien DM tipe 2 seperti kecemasan, depresi, kepatuhan diet, aktivitas fisik, kontrol gula darah, kelelahan, dan stress $[29,30,31]$. Faktor-faktor tersebut perlu untuk dikaji dengan tujuan untuk membuat kualitas hidup pada klien DM tipe 2 semakin mengalami peningkatan.

\section{Simpulan dan Saran}

Tidak terdapat hubungan antara mekanisme koping dengan kualitas hidup klien DM tipe 2 di wilayah kerja Puskesmas Kaliwates. Faktor-faktor lain perlu dikaji seperti kecemasan, depresi, kepatuhan diet, aktivitas fisik, kontrol gula darah, kelelahan, dan stress dengan tujuan untuk meningkatkan kualitas hidup pada klien DM tipe 2.

Penelitian ini diharapkan memberikan tambahan informasi mengenai koping klien DM tipe 2. Perawat dapat memberikan edukasi terkait pentingnya koping pada klien maupun keluarga dari klien DM tipe 2 melalui intervensi keperawatan peningkatan koping. Selain itu diharapkan dapat melibatkan komunitas dalam pemberian edukasi dan membentuk support grup untuk mengingkatkan kualitas hidup bagi klien DM.

Penelitian yang selanjutnya diharapkan dapat meneliti faktor-faktor lain yang dapat berpengaruh terhadap kualitas hidup klien DM tipe 2 seperti kecemasan, stres, depresi, aktivitas fisik, kontrol gula darah dan kepatuhan diet.

\section{Daftar Pustaka}

[1] Sirait AM, Sulistiowati E, Sihombing $M$, Kusuma A, \& Idayani S. Insiden dan faktor risiko diabetes melitus pada orang penyakit tidak menular (incident and risk factor of diabetes mellitus in adults at bogor). Buletin Penelitian Sistem Kesehatan [Internet] 2015 [cited 20 September 2018]; 18(2):151-160. Available from: 
https://media.neliti.com/media/publication s/20939-ID-incident-and-risk-factor-ofdiabetes-mellitus-in-adults-at-bogorprospective-coh.pdf

[2] International Diabetes Federation. Diabetes atlas [Internet]. America: International Diabetes Federation; 2017 [cited 18 Agustus 2018]. Available from: http://www.diabetesatlas.org/

[3] Adikusuma WD, Perwitasari, \& Supadmi. Evaluasi kualitas hidup pasien diabetes melitus tipe 2 rumah sakit umum pku muhammadiyah bantul [Internet]. Bantul: Universitas Ahmad Dahlan; 2018 [cited 26 November 2018]. Available from: http://eprints.uad.ac.id/2281/

[4] Siwiutami F. Kualitas hidup pada penyandang diabetes melitus di wilayah puskesmas purwosari surakarta. Naskah Publikasi. Surakarta: Fakultas IImu Kesehatan Universitas Muhammadiyah Surakarta; 2017.

[5] Yudianto K, Rizmadewi H, \& Maryati I. Kualitas hidup penderita diabetes melitus di rumah sakit umum daerah cianjur. Majalah Keperawatan Unpad. 2010; 10(18):76-87.

[6] Mandagi AM. Faktor yang berhubungan dengan status kualitas hidup penderita diabetes melitus (studi di puskesmas pakis kecamatan sawahan kota surabaya). Skripsi Thesis. Fakultas Keperawatan: Universitas Airlangga; 2010.

[7] Yusra A. 2011. Hubungan antara dukungan keluarga dengan kualitas hidup pasien diabetes melitus tipe 2 di poliklini penyakit dalam rumah sakit umum pusat fatmawati jakarta. Tesis. Fakultas IImu Keperawatan Universitas Indonesia, Jakarta; 2011.

[8] Zainuddin, Utomo W, \& Herlina. 2015. Hubungan stres dengan kualitas hidup penderita diabetes mellitus tipe 2. Journal of Medicine UNRI [Internet]. 2015 [ cited 28 September 2018]; 2(1): [pp.890-898]. Available from: https://jom.unri.ac.id/index.php/JOMPSIK/ article/view/5213

[9] Armiyati $Y$ \& Rahayu DA. Faktor yang berkorelasi terhadap mekanisme koping pasien ckd yang menjalani hemodialisis di rsud kota semarang [Internet]. Semarang: Universitas Muhammadiyah Semarang; 2014 [cited 5 Oktober 2018]. Available from:

e-Journal Pustaka Kesehatan, vol.7 (no. 2), Mei 2019 https://jurnal.unimus.ac.id/index.php/psn1 2012010/article/view/1220

[10] American Association of Diabetes Educators. Standards for outcome measures diabetes self management learning. [internet]. America; 2003. [cited 28 November 2018]. Available from: https://doi.org/10.1177/014572170302900 510

[11] Rubin R \& Peyrot M. Quality of life and diabetes melitus. Diabetes/Metabolism Research and Reviews. 1999 March: 205-218.

[12] Muttaqin A. Pengantar asuhan keperawatan dengan gangguan sistem persarafan. Jakarta: Salemba Medika; 2008.

[13] Potter PA \& Perry AG. Buku ajar fundamental: konsep, proses, dan praktik volume 2. Jakarta: EGC; 2005

[14] Juliansyah T, Elita $V$, \& Bayhakki. Hubungan dukungan keluarga dengan mekanisme koping pasien diabetes melitus. Jurnal Online Mahasiswa Program Studi IImu Keperawatan Universitas Riau [Internet]. 2014 [cited 15 September 2018]; 1(2) : [pp.1-9]. Available from: https://www.neliti.com/id/publications/1892 05/hubungan-dukungan-keluarga-denganmekanisme-koping-pasien-diabetesmellitus

[15] Isnaini N \& Ratnasari R. Faktor risiko mempengaruhi kejadian diabetes mellitus tipe dua. Jurnal Kebidanan dan Keperawatan Aisyiyah [Internet] 2018 [cited 19 September 2018] 14(1): [pp. 5968]. Available from: https://www.researchgate.net/publication/ 327725771 Faktor risiko mempengaruhi kejadian Diabetes mellitus tipe dua

[16] Suyanto \& Susanto A. Faktor-faktor yang berhubungan dengan kejadian neuropati perifer diabetik. Nurscope. Jurnal Keperawatan dan Pemikiran IImiah [Internet]. 2016 [cited 28 Februari 2019]; 2 (6). 1-7. Available from: http://jurnal.unissula.ac.id/index.php/jnm/a rticle/download/834/681

[17] Fatimah RN. Diabetes melitus tipe 2. [Internet] Lampung: Fakultas Kedokteran Universitas Lampung; 2015. Available from:

http://juke.kedokteran.unila.ac.id/index.ph p/majority/article/viewFile/615/619 
[18] Bertalina B \& Anindyati A. Hubungan pengetahuan terapi diet dengan indeks glikemik bahan makanan yang dikonsumsi pasien diabetes mellitus. Jurnal Kesehatan. [Internet] 2016 [cited 27 November 2018] 7(3) : [pp.377-387]. Available from: https://ejurnal.poltekkestjk.ac.id/index.php/JK/article/view/219/205

[19] Parildar H, Cigerli O, \& Demirag NG. Depression, coping strategies, glycemic control and patient compliance in type 2 diabetic patients in an endocrine outpatient clinic. Pakistan Journal of Medical Sciences. 2015; 31(1), 19.

[20] Hidayati A. Hubungan helath locus of control dengan mekanisme koping pada pasien diabetes melitus tipe 2 di wilayah kerja puskesmas patrang kabupaten jember. Tidak diterbitkan. Skripsi. Jember: Fakultas Keperawatan Universitas Jember; 2017.

[21] Jamaluddin M. Strategi coping stres penderita diabetes mellitus dengan self monitoring sebagai variabel mediasi. Malang; 2012 [cited 29 Februari 2019]. Available from: https://media.neliti.com/media/publication s/242508-strategi-coping-stres-penderitadiabetes-29470435.pdf

[22] Sadikin LM \& Subekti EMA. Coping stres pada penderita diabetes mellitus pasca amputasi. Jurnal Psikologi Klinis dan Kesehatan Mental [Internet] 2013 [cited 15 Oktober 2018]; 2(03), 17-23. Available from:

http://journal.unair.ac.id/filerPDF/jpkk7b92 cdae5ffull.pdf

[23] Carver CS, Scheier MF, \& Weintraub JK. Assessing coping strategies: a theoretically based a: roach. Journal of personality and social psychology [Internet] 1989 [cited 19 September 2018] 56(2) : [pp.267-283]. Available from: https://pdfs.semanticscholar.org/5a8c/2bc eefede7391164c9d45ff01f1d4619ba46.pdf

[24] Wahyuni T. Hubungan antara harga diri dengan kualitas hidup pasien diabetes mellitus tipe 2 di rsud" kanjuruhan" kepanjen kabupaten malang. Doctoral dissertation. Malang: University of Muhammadiyah Malang; 2014.
[25] Adikususma W, Perwitasari DA, \& Supadmi W. Pengukuran kualitas hidup pasien diabetes melitus tipe 2 yang mendapat antidiabetik oral di rumah sakit pku muhammadiyah bantul yogyakarta. Jurnal IImiah Ibnu Sina [Internet]. 2016 Januari [cited 19 November];1(1): [pp.18]. Available from: http://jiis.akfarisfibjm.ac.id/

[26] Rahayu FM. Hubungan pemberdayaan diri dengan kualitas hidup pada pasien diabetes melitus tipe II di poli penyakit dalam rs tingkat III baladhika husada jember. Tidak diterbitkan. Skripsi. Jember: Fakultas Keperawatan Universits Jember; 2018.

[27] Pichon-Riviere A, Irazola V, Beratarrechea A, Alcaraz A, \& Carrara C. Quality of life in type 2 diabetes mellitus patients requiring insulin treatment in Buenos Aires, Argentina: a cross-sectional study. International journal of health policy and management. 2015; 4(7), 475.

[28] Bulechek G, Butcher H, Dotcterman J, \& Wagner C. Nursing Intervention Classification (NIC). 6th Edition. Singapore: Elsevier; 2013.

[29] Utami DT, Karim D, \& Agrina. Faktorfaktor yang mempengaruhi kualitas hidup pasien diabetes melitus dengan ulkus diabetikum. Jurnal Online Mahasiwa Psik [Internet]. 2014 [cited 12 September 2018]; 1(2): 1-7. Available from: https://media.neliti.com/media/publication s/187007-ID-faktor-faktor-yangmempengaruhi-kualitas.pdf

[30] Timar R, Velea I, Timar B, Lungeanu D, Oancea C, Roman D, \& Mazilu O. Factors influencing the quality of life perception in patients with type 2 diabetes mellitus. Patient preference and adherence. 2016; 10, 2471.

[31] Kumar R, Krishan P, \& Jhajj R. Healthrelated quality of life and factors affecting it in type-2 diabetic nephropathy patients: a cross sectional observational study. International Journal of Research in Medical Sciences. 2016; 4(5), 1511-1517. 